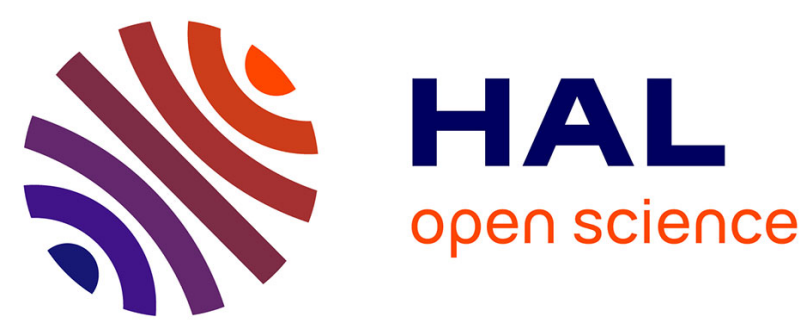

\title{
Oestrogen receptors and small nuclear ring finger protein in malignant ovarian germ cell tumours
}

Jonna Salonen, Ralf Butzow, Jorma J. Palvimo, Markku Heikinheimo, Oskari Heikinheimo

\section{- To cite this version:}

Jonna Salonen, Ralf Butzow, Jorma J. Palvimo, Markku Heikinheimo, Oskari Heikinheimo. Oestrogen receptors and small nuclear ring finger protein in malignant ovarian germ cell tumours. Molecular and Cellular Endocrinology, 2009, 307 (1-2), pp.205. 10.1016/j.mce.2009.03.015 . hal-00499125

\section{HAL Id: hal-00499125 https://hal.science/hal-00499125}

Submitted on 9 Jul 2010

HAL is a multi-disciplinary open access archive for the deposit and dissemination of scientific research documents, whether they are published or not. The documents may come from teaching and research institutions in France or abroad, or from public or private research centers.
L'archive ouverte pluridisciplinaire HAL, est destinée au dépôt et à la diffusion de documents scientifiques de niveau recherche, publiés ou non, émanant des établissements d'enseignement et de recherche français ou étrangers, des laboratoires publics ou privés. 


\section{Accepted Manuscript}

Title: Oestrogen receptors and small nuclear ring finger protein in malignant ovarian germ cell tumours

Authors: Jonna Salonen, Ralf Butzow, Jorma J. Palvimo, Markku Heikinheimo, Oskari Heikinheimo

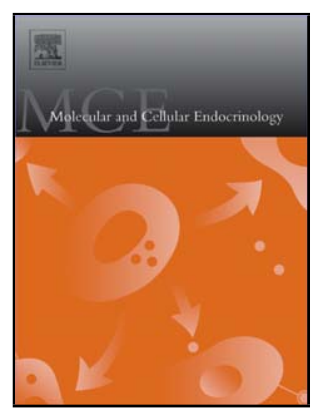

PII:

S0303-7207(09)00205-6

DOI: doi:10.1016/j.mce.2009.03.015

Reference: MCE 7187

To appear in: $\quad$ Molecular and Cellular Endocrinology

Received date: $\quad$ 18-1-2009

Revised date: $\quad$ 7-3-2009

Accepted date: $\quad$ 24-3-2009

Please cite this article as: Salonen, J., Butzow, R., Palvimo, J.J., Heikinheimo, M., Heikinheimo, O., Oestrogen receptors and small nuclear ring finger protein in malignant ovarian germ cell tumours, Molecular and Cellular Endocrinology (2008), doi:10.1016/j.mce.2009.03.015

This is a PDF file of an unedited manuscript that has been accepted for publication. As a service to our customers we are providing this early version of the manuscript. The manuscript will undergo copyediting, typesetting, and review of the resulting proof before it is published in its final form. Please note that during the production process errors may be discovered which could affect the content, and all legal disclaimers that apply to the journal pertain. 


\title{
Oestrogen receptors and small nuclear ring finger protein in malignant ovarian germ cell tumours
}

\author{
Jonna Salonen $^{1,2,3}$, Ralf Butzow ${ }^{4}$, Jorma J. Palvimo ${ }^{5}$, Markku Heikinheimo ${ }^{1,3,6}$, \\ Oskari Heikinheimo $^{2,3}$
}

1. Paediatric Research Centre, Children's Hospital, PO Box 20, SF00014, and Institute of Biomedicine, University of Helsinki, Helsinki, Finland

2. Department of Obstetrics and Gynaecology, Helsinki University Central Hospital, Helsinki, PO Box 140, SF-00029, Helsinki, Finland

3. Program for Women's Health, Biomedicum Helsinki, Helsinki, Finland

4. Department of Pathology, Helsinki University Central Hospital, PO Box 400, SF-00029 Helsinki, Finland

5. Institute of Biomedicine/Medical Biochemistry, University of Kuopio, PO Box 1627, SF-70211, Kuopio, Finland

6. Department of Paediatrics, Washington University School of Medicine, St. Louis, Missouri, USA

\section{Correspondence}

Markku Heikinheimo, MD, PhD

Children's Hospital, University of Helsinki, PO Box 63, SF-00014 Helsinki, Finland

Tel. +358 50427 2879, Fax +358 9471 71947, e-mail

markku.heikinheimo@helsinki.fi 


\begin{abstract}
The peak incidence of malignant ovarian germ cell tumours occurs soon after puberty. Thus, gonadal steroids may play a role in their development.

Oestrogen receptors (ER $\alpha$ and $E R \beta)$ and their co-regulators, including small nuclear ring finger (SNURF/RNF4) protein mediate oestrogen actions. While ER $\beta$ and SNURF are down-regulated in testicular germ cell tumours, their role in the ovarian germ cell tumours remains unknown.
\end{abstract}

We herein studied the different subtypes of malignant ovarian germ cell tumours, and found that they all express ER $\alpha, E R \beta$, and SNURF. Stimulation with oestradiol (E2), ER $\alpha, E R \beta$ and SNURF significantly up-regulated mRNA expression in the human germinoma derived NCC-IT cells. Further, the effects of E2 were counteracted by an anti-oestrogen (ICI 182,780). Neither E2 nor ICI 182,780 had an effect on the proliferation of NCC-IT cells as assessed by flow cytometric analysis. Our results suggest that oestrogen signalling has a role in malignant ovarian germ cell tumours.

\title{
Keywords
}

Oestradiol, oestrogen receptor, ovarian germ cell tumour, small nuclear ring finger protein (SNURF/RNF4) 


\section{Introduction}

Malignant ovarian germ cell tumours (MOGCTs) are rare tumours representing less than $5 \%$ of all ovarian malignancies (Pectasides et al., 2008). Histologically they are a heterogeneous group including various subtypes (dysgerminomas, yolk sac tumours, immature teratomas, embryonal carcinomas) (Pectasides et al., 2008). They may also harbour a mixture of these different subtypes. These different germ cell tumour types are thought to develop from pluripotent primordial germ cells. However, relatively little is still known about the molecular biology of germ cell tumours. The peak incidence of MOGCTs occurs soon after puberty, at an age of less than 20 (Tewari et al., 2000). Thus, gonadal steroids may have a role in their tumorigenesis.

Understanding of steroid hormone action and its regulation has increased considerably in recent decades. Regarding the regulation of oestrogen signalling, two distinct oestrogen receptors (ERs) have been identified (ER $\alpha$ and ER $\beta)($ Walter et al., 1985, Mosselman et al., 1996). Knockout mouse models have revealed the roles of ERs in normal ovarian physiology and folliculogenesis (Lubahn et al., 1993, Couse and Korach, 1998). The human ovary expresses both ERs. Oestrogen receptor beta is localized to granulosa cells, whereas ER $\alpha$ is localized to the theca and interstitial cells (Pelletier and El-Alfy, 2000). Ovarian epithelial cells express both ER! and ER! (Hillier et al., 1998). In the developing human ovary, ERs are expressed from the $20^{\text {th }}$ week of pregnancy onwards and their expression is localized to the granulosa cells and oocytes (Vaskivuo et al., 2005).

In contrast to the ovary, human testicular germ cells and Sertoli cells express only ER $\beta$ (Carreau et al., 2006). The expression of ER $\beta$ is markedly diminished in testicular seminomas, embryonal carcinomas and mixed germ 
cell tumours, both at transcriptional and translational levels (Pais et al., 2003). In contrast, the expression of ER $\beta$ remains normal in testicular yolk sac tumours and teratomas (Pais et al., 2003). However, ER expression in human MOGCTs has not been assessed previously.

Steroid receptor action is regulated by multiple co-regulators (Hermanson et al., 2002). Small nuclear RING finger protein (SNURF/RNF4) is one of these co-regulators, and it can co-activate both androgen- and oestrogen-dependent transcription by interacting directly with the corresponding steroid receptors (Moilanen et al., 1998). In murine foetal testis, SNURF is localized to gonocytes and to Leydig and Sertoli cells, whereas in murine foetal ovary it is present in the oogonia and granulosa cells (Hirvonen-Santti et al., 2004). The expression of ovarian SNURF is up-regulated in immature mice following oestradiol (E2) treatment. The expression of SNURF has been found to be down-regulated in human testicular germ cell cancer as compared with normal testicular tissue (Hirvonen-Santti et al., 2003). The potential role of SNURF in MOGCTs has not been studied.

In order to study the role of oestrogen action in ovarian germ cell tumours, we characterized for the first time the expression of ER $\alpha, E R \beta$ and SNURF in MOGCTs. In addition, in vitro studies were carried out using the human germ cell tumour cell line NCC-IT. This cell line, obtained from a mediastinal mixed germ cell tumour, is unique in that it expresses markers of both pluripotent germ cells and embryonal stem cells (Damjanov et al., 1993). It may thus be a suitable in vitro model for ovarian dysgerminoma.

\section{Materials and Methods}

Patients 
Approval for the study was obtained from the Ethics Committee of the

Department of Obstetrics and Gynaecology, University of Helsinki, and from the National Authority for Medicolegal Affairs. Tumour samples $(n=14)$, originally collected for diagnostic purposes at the Department of Obstetrics and Gynaecology, Helsinki University Central Hospital, between 1982 and 2002 were used for the present study. The mean age was 28.9 years (range 12-49), all of the patients were postpubertal. Of the MOGCT specimens, 5 were dysgerminomas (DGs), 5 were yolk sac tumours (YSTs), 4 were immature teratomas (ITs) and there was one mixed tumour with DG and embryonal carcinoma (EC) components.

\section{Cell lines}

The NCC-IT human germinoma cell line (Teshima et al., 1988) was obtained from The American Type Culture Collection (Manassas, VA, USA). The cells were cultured in RPMI-1640 medium (Gibco, Invitrogen Corporation, Carlsbad, CA, USA) supplemented with foetal bovine serum (10\%) and penicillin-streptomycin (1\%).

\section{Immunohistochemistry}

The antibody used for immunohistochemistry of ER $\alpha$ was from DakoCytomation, (Glostrup, Denmark) (M7047), and that for ER $\beta$ was from Serotec, (Oxford, UK) (MCA1974s). The anti-SNURF antibody has been described previously (Häkli et al., 2005). The tissue sections from paraffinembedded tissue blocks were deparaffinised and rehydrated using descending concentrations of ethanol. Antigen retrieval was performed by incubating the slides in $0.1 \mathrm{M}$ citric acid (pH 8.0) at approximately $100{ }^{\circ} \mathrm{C}$ for $20 \mathrm{~min}$. Endogenous peroxidase activity was blocked with $3 \% \mathrm{H}_{2} \mathrm{O}_{2}$ in water for 5 min. An avidin-biotin immunoperoxidase system was used to visualize bound antibody (Vectastain Elite ABC Kit, Vector Laboratories, Burlingame, CA, USA), with 3,3'-diaminobenzidine (Sigma, St. Louis, MO, USA) as 
chromogen. In negative control experiments PBS replaced the primary

antibody. Scoring of the antigens was based on the staining intensity of at least $10 \%$ of the tumour cells, divided into three categories: no staining (-), weak staining $( \pm)$, positive staining $(+,++$ or +++$)$. The staining intensity of ER! was compared with that of ER!.

\section{Stimulation of NCC-IT cells with oestradiol}

The cells were plated on 12-well dishes at a density of $25 \times 10^{5}$ per well and incubated in RPMI-1640 (phenol red-free) supplemented (10\%) with dextrancharcoal-treated foetal bovine serum (HyClone, Logan, UT, USA) for $48 \mathrm{~h}$ before stimulation. They were stimulated with 17!-estradiol (E2) (Sigma, St. Louis, MO, USA) at concentrations of 1 to $1000 \mathrm{nM}$ for 24 to $120 \mathrm{~h}$ to determine time- and dose-responses of the expression of ERs and their coactivator SNURF. For control experiments, the anti-oestrogen ICI 182,780 (Tocris Cookson Ltd, Bristol, UK) was added at a concentration of $1000 \mathrm{nM}$ simultaneously with $1 \mathrm{nM} \mathrm{E} 2$. The concentrations of E2 and anti-oestrogen were based on those used in previous reports (Martin et al., 2005). All incubations were performed in duplicate and repeated at least three times. Untreated and vehicle-only-treated controls were included in each experiment.

\section{Semi-quantitative RT-PCR}

Cells were collected at different time points (24-120 h) after stimulation, and total RNA was isolated by using RNeasy kit (Qiagen, Hilden, Germany). Purified RNA $(1 \mu \mathrm{g})$ was reverse-transcribed and $2 \mu \mathrm{L}$ of the reaction mixture was used for each PCR reaction. The primers and thermal cycler conditions are presented in Table 1. The number of cycles used for PCR were

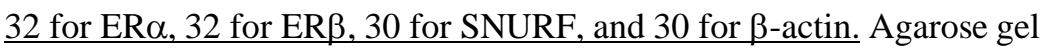
electrophoresis (2\%), run in the presence of SybrSafe ${ }^{\mathrm{TM}}$ DNA gel stain (Invitrogen Corporation, Carlsbad, CA, USA) demonstrated PCR products of 
expected size (Fig 2A, B) for each of the PCR primer pairs. Threshold cycles were normalized to threshold cycles for $\beta$-actin. The intensities of the bands were analysed by using the Bio-Rad Gel Doc program (Bio-Rad Laboratories, Hercules, CA, USA) and quantified by using Quantity One software (Bio-Rad Laboratories).

Flow cytometric analysis

To analyse the proliferation of the cells APC BrdU Flow Kit (BD

Biosciences, BD Biosciences, San Jose, CA, USA) was used following the staining protocol by the manufacture. After E2 or anti-oestrogen ICI 182,780 $\underline{\text { stimulation cells were labelled with BrdU (an analog of the DNA precursor }}$ $\underline{\text { thymidine) at concentration of } 10 \mu \mathrm{M} \text {. Cells were harvested at different time }}$ points ( 6 to $48 \mathrm{~h}$ ), fixed, and stained with anti-BrdU specific APC fluorochrome according to manufactures protocol. Cells with incorporated $\underline{\text { BrdU indicating proliferating cells were analysed by flow cytometry }}$ (FACSAria, BD Biosciences).

\section{Statistical analysis}

Data are expressed as mean values \pm SEM derived from three independent experiments, all with two replicates, and adjusted to a value of 1.0 for the mean of the first control culture. The E2 and ICI 182,780 stimulation data were analysed using Student's $t$ test. A $p$ value $<0.05$ was considered statistically significant. The statistical software used was SPSS, version 15.0 (SPSS Inc., Chicago, IL, USA).

\section{Results}

$E R \alpha, E R \beta$ and SNURF (RNF4) are expressed in normal ovarian oocytes, MOGCTs and NCC-IT cells 
In normal ovary, expression of ER $\alpha, E R \beta$ and SNURF was localized to the oocytes (Figure 1C, F, I). All histological types of MOGCTs studied expressed ER! (Figure 1A,B, Table2) and ER $\beta$ (Figure 1D,E, Table 2). Expression of ER! was stronger than ER! in all MOGCT specimens with an exception of one YST (Table 2). In addition, all MOGCT subtypes expressed SNURF localized into the nucleus and cytoplasm (Figure 1G, H, Table 2). In line with the expression of dysgerminomas human germinoma derived cell line (NCC-IT) expressed both ER $\alpha$ and ER $\beta$ as well as their co-receptor SNURF (Figure 1A, D, G insets).

Stimulation of NCC-IT cells with E2 increased the mRNA expression of ER!,

\section{ER! and SNURF}

Expression of ER $\alpha$ and $E R \beta$ mRNA was increased at all time points (24-120

h) following stimulation with E2 at all concentrations (1-1000 nM) tested, and at $48 \mathrm{~h}$ the increases were statistically significant (Figure 2A, B, C). The maximal increase in the expression of ER $\alpha$ was seen at $72 \mathrm{~h}$, with $100 \mathrm{nM}$ E2 (Figure 2B). With the lowest concentration $(1 \mathrm{nM})$ used, ER $\alpha$ expression reached its maximum as soon as at $48 \mathrm{~h}(p<0.05)$. Expression of ER $\beta$ mRNA reached its maximum at $48 \mathrm{~h}(p<0.005)$ (Figure 2A). The increased expression of ERs after stimulation with $1 \mathrm{nM} \mathrm{E} 2$ was blocked by the antioestrogen ICI 182,780 (1000 nM) at $48 \mathrm{~h}$ (Figure 3).

Stimulation with E2 increased SNURF mRNA expression levels during the 5-day period at all time points (24-120 h) and with all tested concentrations (1-1000 nM) of E2 (Figure 2C). The maximal increase was seen at $48 \mathrm{~h}$, with $100 \mathrm{nM}$ E2 $(p<0.05)$ (Figure 2B). Increased expression of SNURF was evident even at the lowest concentration $(1 \mathrm{nM})$ at $24 \mathrm{~h}(p<0.05)$ and $48 \mathrm{~h}$ $(p<0.005)$ after stimulation (Figure 2A, B). The increased expression of SNURF induced by E2 at $48 \mathrm{~h}$ was inhibited by the anti-oestrogen ICI 182,780 (Figure 3). 
Neither E2 nor the anti-oestrogen ICI 182,780 had an effect on NCC-IT cell proliferation as assessed by flow cytometric analysis. The percent of the proliferating NCC-IT cells in the control group was 47.7\% (range 43.9-

$\underline{54.5 \%)}$ at 24 hours, and $48.3 \%(42.2-54.2)$ in E2 the stimulation group. At 48 hours, the corresponding figures were $56.7 \%$ (53.6-59.7), and $55.4 \%(52.8-$ 58.8), respectively. There were no obvious morphological changes in the NCC-IT cells after exposure to E2 nor anti-oestrogen (data not shown).

\section{Discussion}

Two thirds of epithelial ovarian cancer specimens express ERs (Lindgren et al., 2004) and anti-oestrogen therapy with tamoxifen has resulted in modest responses in cases of recurrent ovarian cancer (Makar, 2000). Thus, oestrogens might have a role in the pathogenesis of epithelial ovarian cancer. Moreover, the use of oestrogen therapy, such as administration of combined oral contraceptives (COCs), or hormone therapy (HT) of menopausal symptoms, is associated with an altered incidence of epithelial ovarian cancer (Rossing et al., 2007, Lurie et al., 2008). The potential role of hormone therapy in the pathogenesis of MOGCTs has not been assessed. This may be a result of the rarity of these tumours and the fact that they are usually diagnosed during adolescence.

The expression of ERs, or their modulators, has not been assessed previously in malignant ovarian germ cell tumours. We herein find that all histological subtypes of MOGCTs expressed both ER $\alpha$ and ER $\beta$. In addition, these tumours expressed the ER co-regulator SNURF. Thus, oestrogens might have a role in ovarian germ cell tumour pathogenesis. We speculate that the stimulatory effect of oestrogens on primordial germ cells occurs when the 
pituitary-ovarian axis is activated at the time of puberty. This may trigger the development of MOGCT.

Several studies have demonstrated a decrease in ER $\beta$ and/or an increase in the ER!/! ratio in epithelial ovarian cancer in comparison with normal ovarian tissue (Brandenberger et al., 1998, Pujol et al., 1998, Rutherford et al., 2000, Bardin et al., 2004). Furthermore, an increased ER!/! ratio has been reported in breast (Roger et al., 2005), prostate (Fixemer et al., 2003) and colorectal carcinoma (Campbell-Thompson et al., 2001). The results of recent studies with ovarian, prostate and breast cancer cell lines have indicated a role of ER $\beta$ as a tumour suppressor in these hormone-responsive organs (Bardin et al., 2004, Lazennec et al., 2001, Cheng et al., 2004). In the present study, expression of ER! was stronger than that of ER! in most of the MOGCT specimens analysed. In addition, both ER $\alpha$ and ER $\beta$ were expressed in NCC-IT cells. Thus, in contrast to several other types of tumours, ER! might not play a suppressor role in ovarian germ cell tumours.

Oestrogens modulate the expression of ERs in a tissue- and cell type-specific fashion. Thus, stimulation with oestrogen has diverse effects on different tumour types (Clayton et al., 1997, Vladusic et al., 2000, Le et al., 2006). It is known, that oestrogen enhances proliferation of ER-positive ovarian epithelial cancer cell lines (Galtier-Dereure et al., 1992, Langdon et al., 1994). Furthermore, E2 stimulates cell proliferation both in prostate and breast cancer cell lines (Martin et al., 2005, Arnold et al., 2005), whereas decreased proliferation has been reported in a human seminoma (a counterpart of female dysgerminoma) cell line (Roger et al., 2005). In addition, estradiol has non-genomic actions through membrane-mediated activation of extracellular regulated kinase and protein kinase A, resulting stimulation of proliferation of seminoma cells (Bouskine et al., 2008). 
We now found that E2 increased expression of both ER! and ER! in the germinoma derived NCC-IT cell line. Similarly to ERs, SNURF mRNA was increased following stimulation with E2, which is in line with augmented SNURF mRNA expression in mouse ovaries following E2 treatment (Hirvonen-Santti et al., 2004). However, E2 and the anti-oestrogen ICI 182,780 did not have an effect on the proliferation of the NCC-IT cells. ER $\alpha$ has been reported to act as a suppressor of ER $\beta$ action. As both ER! and ER! were up-regulated following E2 treatment, the lack of oestrogen effect on proliferation of NCC-IT cells could be associated with the balance of ER $\alpha / \beta$, in which the ERs might counteract each other. Unfortunately, due to the paucity of malignant ovarian germ cell tumour derived cell lines oestrogen effects cannot be studied in additional cell lines. Moreover, the results obtained with NCC-IT cell line cannot be directly related to other germ cell tumour types encountered in MOGCTs.

In conclusion, ER $\alpha, \mathrm{ER} \beta$ and their co-regulator SNURF (RNF4) are all expressed in MOGCTs. In addition, in vitro studies on the human germinoma-derived NCC-IT cell line demonstrated increased ER and SNURF expression after stimulation with E2. These data suggest that oestrogen action may have a role in the regulation of MOGCT tumorigenesis.

\section{Conflict of Interests Statement}

No conflict of interest.

\section{Funding}

This work was supported by the Helsinki University Central Hospital

Research Funds, the Sigrid Jusélius Foundation, the Finnish Cancer Organizations, and the National Clinical Graduate School.

\section{Acknowledgments}


We thank Dr. Arto Leminen for his assistance with the MOGCT tumour patient data and Ms. Taru Jokinen for skilful technical assistance.

\section{Legends for Figures}

\section{Figure 1.}

Immunohistochemical expression patterns of ER $\alpha$ (upper panels), ER $\beta$ (middle panels) and SNURF (bottom panels) in DGs (A, D, G), YSTs (B, E, $\mathrm{H})$, the NCC-IT cell line (insets in A, D and G) and in normal ovary (C, F, I). The negative controls are presented as insets in the upper right corner for the $\underline{E R} \alpha, E R \beta$, and SNURF (A, D, G). (arrow head = oocyte, bar $200 \mu \mathrm{m}$, insets $100 \mu \mathrm{m}, \mathrm{DG}=$ dysgerminoma, $\mathrm{YST}=$ yolk sac tumour $)$

\section{Figure 2.}

Effects of oestradiol on the NCC-IT cell line.

\section{A. Effect of E2 $(10 \mathrm{nM})$ on ER!, ER! and SNURF mRNA following 24- to}

72-h stimulation.

\section{B. Effect of E2 $(100 \mathrm{nM})$ on ER!, ER! and SNURF mRNA following 24 to}

72-h stimulation.

C. Effect of E2 (1-1000 nM) on ER!, ER! and SNURF mRNA following 48h stimulation.

Data are expressed as mean values \pm SEM derived from three independent experiments, all with two replicates per experiment. $(\mathrm{E} 2=$ oestradiol, $\mathrm{ICI}=$ anti-oestrogen ICI 182,780, C = control $\left.{ }^{*} p<0.05, * * p<0.005\right)$

\section{Figure 3.}


Effect of oestradiol (1 nM) + anti-oestrogen (ICI 182,780, $1000 \mathrm{nM})$ on ER!, ER! and SNURF mRNA following 48-h stimulation. Data are expressed as mean values \pm SEM derived from three independent experiments, all with two replicates per experiment. $(\mathrm{E} 2=$ oestradiol, $\mathrm{ICI}=$ anti-oestrogen ICI $182,780, \mathrm{C}=$ control $)$ 
Table 1.

Primer sequences and thermal conditions for semi-quantitative PCR.

Forward

Reverse

Expected

A

size (bp) $\mathrm{T}$

ER!

$5^{\prime}$-ggagacatgagagctgccaac-3'

$5^{\prime}$-ccagcagcatgtcgaagatc-3'

$5^{\prime}-$ tccatgccettgttactcg-3'

439

ER

SNURF

$5^{\prime}$-ggccgacaaggagttggt-3'

$5^{\prime}$-gctgtctgtctgtccatccgtctctc-3'

519

$\beta$-actin

5'-cgggaaatcgtgcgtgacattaag-3'

$5^{\prime}$-ttcgtggatgccacaggactcc-3'

213

71

71


Table 2.

Immunohistochemical staining of ER $\alpha, E R \beta$ and SNURF in different histological subtypes of human malignant ovarian germ cell tumors. Percent of the positively staining tumor cells is presented in parenthesis.

Diagnosis Stage Survival ER! ER! ER $\alpha / E R \beta \quad$ SNURF

$\begin{array}{lllllll}\mathrm{DG}^{*} & \mathrm{IIIC} & \mathrm{EX} & +(80) & ++ & \downarrow & ++(15)\end{array}$

(80)

$\mathrm{DG} \quad \mathrm{IC} \quad \mathrm{CR} \quad+(15) \quad++\quad \downarrow \quad+(80)$

(80)

DG

IIIC $\mathrm{CR} \quad++\quad++\quad=$

DG

IIA $\quad \mathrm{CR}+(80)+$

(80) (50)

$(80)$

DG

$\mathrm{IC}$

CR

$\pm(80)$ $++(15)$

(80)

YST

IIIA CR

+++

$+++=$

$+++(50)$

(50) (80)

YST

IA CR

$\begin{array}{lll}+++ & ++ & \uparrow\end{array}$

$+++(50)$

(80) (50)

$\begin{array}{lllllll}\text { YST } & \text { IC } & \text { CR } & ++ & ++ & = & \pm(15) \\ & & & (80) & (80) & & \\ \text { YST } & \text { IIIA } & \text { CR } & +(80) & ++ & \downarrow & \pm(15) \\ & & & & (80) & & \\ \text { YST } & \text { IIIC } & \text { EX } & - & ++ & \downarrow & ++(50) \\ \text { IT } & \text { IIIC } & \text { EX } & +(15) & ++ & \downarrow & +(15) \\ & & & & (80) & & \\ \text { IT } & \text { IC } & \text { EX } & +(15) & +++ & \downarrow & \pm(15) \\ & & & & (50) & & \\ \text { IT } & \text { IC } & \text { CR } & +(50) & +++ & \downarrow & \pm(15)\end{array}$


EX $+(50)$

(80)

*DGs included one mixed tumour with DG and embryonal carcinoma (EC) components. DG, dysgerminoma; YST, yolk sac tumour; IT, immature teratoma; EX, died; CR, complete response; $\downarrow$, ER $\alpha / E R \beta$ ratio decreased; ; $\uparrow, \mathrm{ER} \alpha / \mathrm{ER} \beta$ ratio elevated; =, ER $\alpha / \mathrm{ER} \beta$ ratio equal.

\section{References}

Arnold, J.T., Le, H., McFann, K.K., Blackman, M.R., 2005. Comparative effects of DHEA vs. testosterone, dihydrotestosterone, and estradiol on proliferation and gene expression in human LNCaP prostate cancer cells. Am J Physiol Endocrinol Metab.288, E573-84.

Bardin, A., Boulle, N., Lazennec, G., Vignon, F., Pujol, P., 2004. Loss of ERbeta expression as a common step in estrogen-dependent tumor progression. Endocr Relat Cancer.11, 537-551.

Bouskine, A., Nebout, M., Mograbi, B., Brücker-Davis, F., Roger, C., Fenichel, P., 2008. Estrogens promote human testicular germ cell cancer through a membrane-mediated activation of extracellular regulated kinase and protein kinase A. Endocrinology.149, 565-573.

Brandenberger, A.W., Tee, M.K., Jaffe, R.B., 1998. Estrogen receptor alpha (ER-alpha) and beta (ER-beta) mRNAs in normal ovary, ovarian serous cystadenocarcinoma and ovarian cancer cell lines: down-regulation of ERbeta in neoplastic tissues. J Clin Endocrinol Metab.83, 1025-1028.

Campbell-Thompson, M., Lynch, I.J., Bhardwaj, B., 2001. Expression of estrogen receptor (ER) subtypes and ERbeta isoforms in colon cancer. Cancer Res.61, 632-640.

Carreau, S., Delalande, C., Silandre, D., Bourguiba, S., Lambard, S., 2006. Aromatase and estrogen receptors in male reproduction. Mol Cell Endocrinol.246, 65-68. 
Cheng, J., Lee, E.J., Madison, L.D., Lazennec, G., 2004. Expression of estrogen receptor beta in prostate carcinoma cells inhibits invasion and proliferation and triggers apoptosis. FEBS Lett.566, 169-172.

Clayton, S.J., May, F.E., Westley, B.R., 1997. Insulin-like growth factors control the regulation of oestrogen and progesterone receptor expression by oestrogens. Mol Cell Endocrinol.128, 57-68.

Couse, J.F. and Korach, K.S., 1998. Exploring the role of sex steroids through studies of receptor deficient mice. J Mol Med.76, 497-511.

Damjanov, I., Horvat, B., Gibas, Z., 1993. Retinoic acid-induced differentiation of the developmentally pluripotent human germ cell tumorderived cell line, NCCIT. Lab Invest.68, 220-232.

Fixemer, T., Remberger, K., Bonkhoff, H., 2003. Differential expression of the estrogen receptor beta (ERbeta) in human prostate tissue, premalignant changes, and in primary, metastatic, and recurrent prostatic adenocarcinoma. Prostate.54, 79-87.

Galtier-Dereure, F., Capony, F., Maudelonde, T., Rochefort, H., 1992.

Estradiol stimulates cell growth and secretion of procathepsin D and a 120-

kilodalton protein in the human ovarian cancer cell line BG-1. J Clin

Endocrinol Metab.75, 1497-1502.

Häkli, M., Karvonen, U., Jänne, O.A., Palvimo, J.J., 2005. SUMO-1 promotes association of SNURF (RNF4) with PML nuclear bodies. Exp Cell Res.304, 224-233.

Hermanson, O., Glass, C.K., Rosenfeld, M.G., 2002. Nuclear receptor coregulators: multiple modes of modification. Trends Endocrinol Metab.13, $55-60$.

Hillier, S.G., Anderson, R.A., Williams, A.R., Tetsuka, M., 1998. Expression of oestrogen receptor alpha and beta in cultured human ovarian surface epithelial cells. Mol Hum Reprod.4, 811-815.

Hirvonen-Santti, S.J., Sriraman, V., Anttonen, M., Savolainen, S., Palvimo, J.J., Heikinheimo, M., Richards, J.S., Jänne, O.A., 2004. Small nuclear RING finger protein expression during gonad development: regulation by gonadotropins and estrogen in the postnatal ovary. Endocrinology.145, 24332444.

Hirvonen-Santti, S.J., Rannikko, A., Santti, H., Savolainen, S., Nyberg, M., Jänne, O.A., Palvimo, J.J., 2003. Down-regulation of estrogen receptor beta and transcriptional coregulator SNURF/RNF4 in testicular germ cell cancer. Eur Urol.44, 742-7; discussion 747.

Langdon, S.P., Hirst, G.L., Miller, E.P., Hawkins, R.A., Tesdale, A.L., Smyth, J.F., Miller, W.R., 1994. The regulation of growth and protein expression by estrogen in vitro: a study of 8 human ovarian carcinoma cell lines. J Steroid Biochem Mol Biol.50, 131-135.

Lazennec, G., Bresson, D., Lucas, A., Chauveau, C., Vignon, F., 2001. ER beta inhibits proliferation and invasion of breast cancer cells.

Endocrinology.142, 4120-4130.

Le, H., Arnold, J.T., McFann, K.K., Blackman, M.R., 2006. DHT and testosterone, but not DHEA or E2, differentially modulate IGF-I, IGFBP-2, and IGFBP-3 in human prostatic stromal cells. Am J Physiol Endocrinol Metab.290, E952-60. 
Lindgren, P.R., Cajander, S., Backstrom, T., Gustafsson, J.A., Mäkelä, S., Olofsson, J.I., 2004. Estrogen and progesterone receptors in ovarian epithelial tumors. Mol Cell Endocrinol.221, 97-104.

Lubahn, D.B., Moyer, J.S., Golding, T.S., Couse, J.F., Korach, K.S., Smithies, O., 1993. Alteration of reproductive function but not prenatal sexual development after insertional disruption of the mouse estrogen receptor gene. Proc Natl Acad Sci U S A.90, 11162-11166.

Lurie, G., Wilkens, L.R., Thompson, P.J., McDuffie, K.E., Carney, M.E., Terada, K.Y., Goodman, M.T., 2008. Combined oral contraceptive use and epithelial ovarian cancer risk: time-related effects. Epidemiology.19, 237243.

Makar, A.P., 2000. Hormone therapy in epithelial ovarian cancer. Endocr Relat Cancer.7, 85-93.

Martin, L.A., Pancholi, S., Chan, C.M., Farmer, I., Kimberley, C., Dowsett, M., Johnston, S.R., 2005. The anti-oestrogen ICI 182,780, but not tamoxifen, inhibits the growth of MCF-7 breast cancer cells refractory to long-term oestrogen deprivation through down-regulation of oestrogen receptor and IGF signalling. Endocr Relat Cancer.12, 1017-1036.

Moilanen, A.M., Poukka, H., Karvonen, U., Häkli, M., Jänne, O.A., Palvimo, J.J., 1998. Identification of a novel RING finger protein as a coregulator in steroid receptor-mediated gene transcription. Mol Cell Biol.18, 5128-5139.

Mosselman, S., Polman, J., Dijkema, R., 1996. ER beta: identification and characterization of a novel human estrogen receptor. FEBS Lett.392, 49-53.

Pais, V., Leav, I., Lau, K.M., Jiang, Z., Ho, S.M., 2003. Estrogen receptorbeta expression in human testicular germ cell tumors. Clin Cancer Res.9, 4475-4482.

Pectasides, D., Pectasides, E., Kassanos, D., 2008. Germ cell tumors of the ovary. Cancer Treat Rev.34, 427-441.

Pelletier, G. and El-Alfy, M., 2000. Immunocytochemical localization of estrogen receptors alpha and beta in the human reproductive organs. J Clin Endocrinol Metab.85, 4835-4840.

Pujol, P., Rey, J.M., Nirde, P., Roger, P., Gastaldi, M., Laffargue, F., Rochefort, H., Maudelonde, T., 1998. Differential expression of estrogen receptor-alpha and -beta messenger RNAs as a potential marker of ovarian carcinogenesis. Cancer Res.58, 5367-5373.

Roger, C., Lambard, S., Bouskine, A., Mograbi, B., Chevallier, D., Nebout, M., Pointis, G., Carreau, S., Fenichel, P., 2005. Estrogen-induced growth inhibition of human seminoma cells expressing estrogen receptor beta and aromatase. J Mol Endocrinol.35, 191-199.

Roger, P., Sahla, M.E., Mäkelä, S., Gustafsson, J.A., Baldet, P., Rochefort, H., 2001. Decreased expression of estrogen receptor beta protein in proliferative preinvasive mammary tumors. Cancer Res.61, 2537-2541.

Rossing, M.A., Cushing-Haugen, K.L., Wicklund, K.G., Doherty, J.A., Weiss, N.S., 2007. Menopausal hormone therapy and risk of epithelial ovarian cancer. Cancer Epidemiol Biomarkers Prev.16, 2548-2556. 
Rutherford, T., Brown, W.D., Sapi, E., Aschkenazi, S., Munoz, A., Mor, G., 2000. Absence of estrogen receptor-beta expression in metastatic ovarian cancer. Obstet Gynecol.96, 417-421.

Teshima, S., Shimosato, Y., Hirohashi, S., Tome, Y., Hayashi, I., Kanazawa, H., Kakizoe, T., 1988. Four new human germ cell tumor cell lines. Lab Invest.59, 328-336.

Tewari, K., Cappuccini, F., Disaia, P.J., Berman, M.L., Manetta, A., Kohler, M.F., 2000. Malignant germ cell tumors of the ovary. Obstet Gynecol.95, 128-133.

Vaskivuo, T.E., Maentausta, M., Torn, S., Oduwole, O., Lonnberg, A., Herva, R., Isomaa, V., Tapanainen, J.S., 2005. Estrogen receptors and estrogen-metabolizing enzymes in human ovaries during fetal development. J Clin Endocrinol Metab.90, 3752-3756.

Vladusic, E.A., Hornby, A.E., Guerra-Vladusic, F.K., Lakins, J., Lupu, R., 2000. Expression and regulation of estrogen receptor beta in human breast tumors and cell lines. Oncol Rep.7, 157-167.

Walter, P., Green, S., Greene, G., Krust, A., Bornert, J.M., Jeltsch, J.M., Staub, A., Jensen, E., Scrace, G., Waterfield, M., 1985. Cloning of the human estrogen receptor cDNA. Proc Natl Acad Sci U S A.82, 7889-7893. 


\section{FIG 1.}

DG

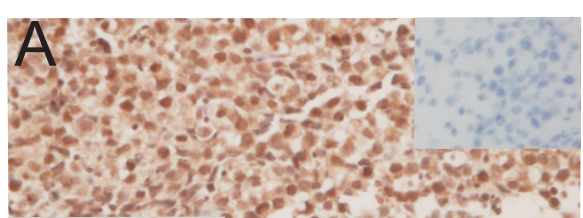

$\mathrm{ER} \alpha$

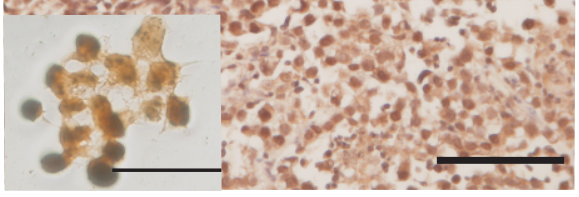

D. 003 m

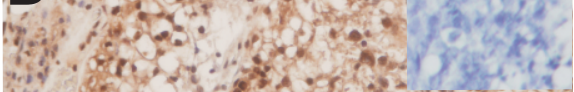

ER $\beta$

SNURF

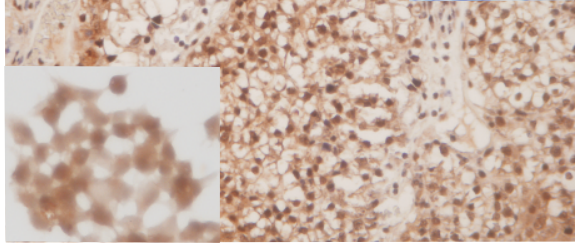

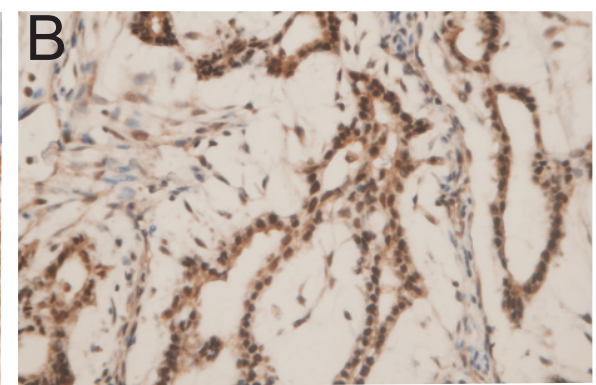

Normal Ovary
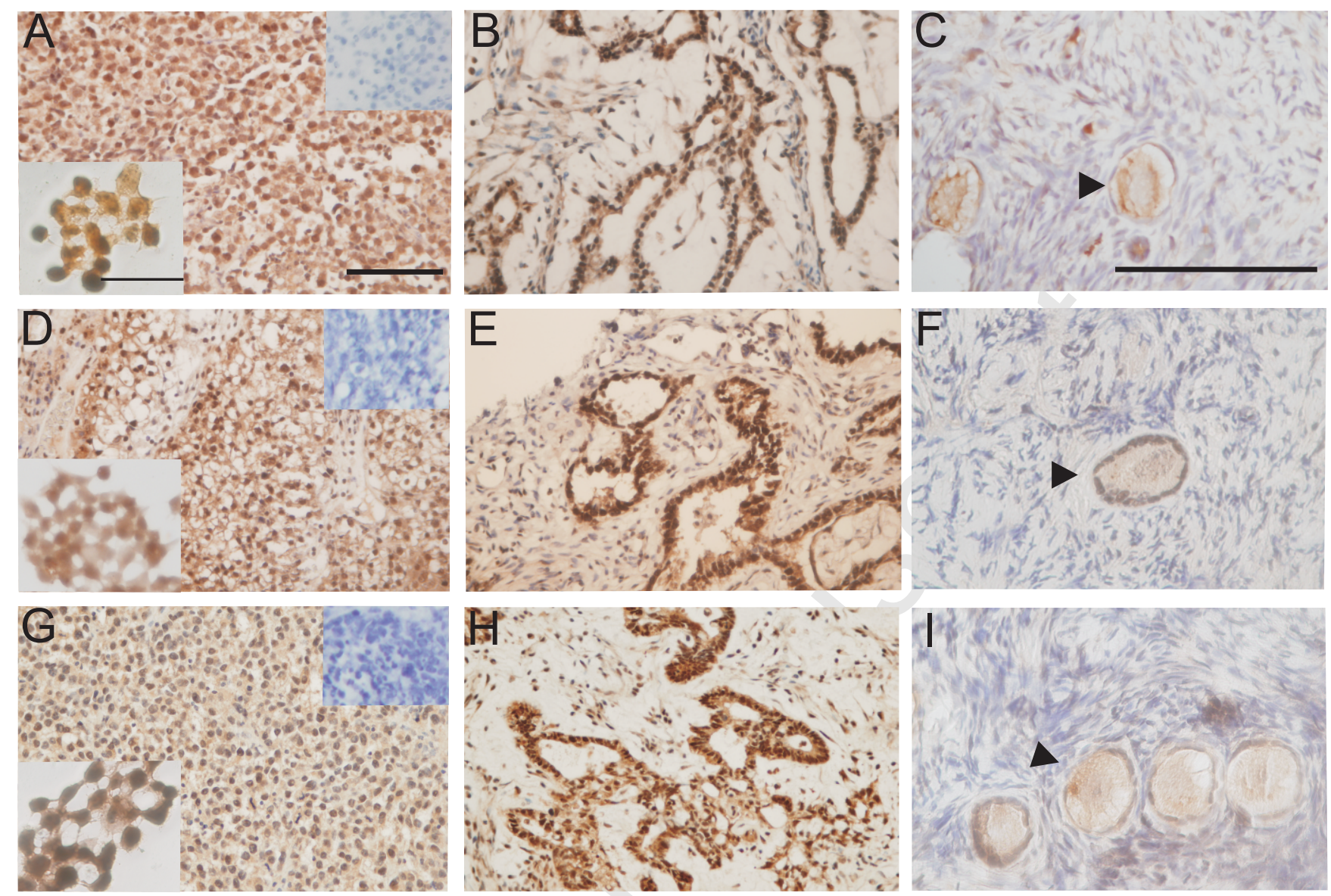
Figure 2.

$\mathrm{ER} \alpha$

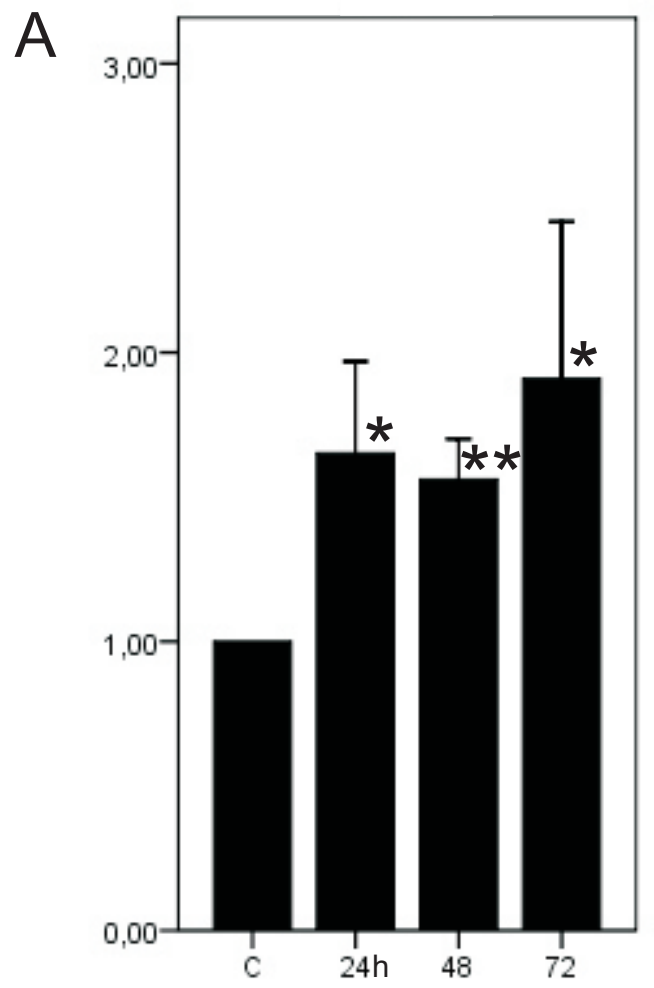

B

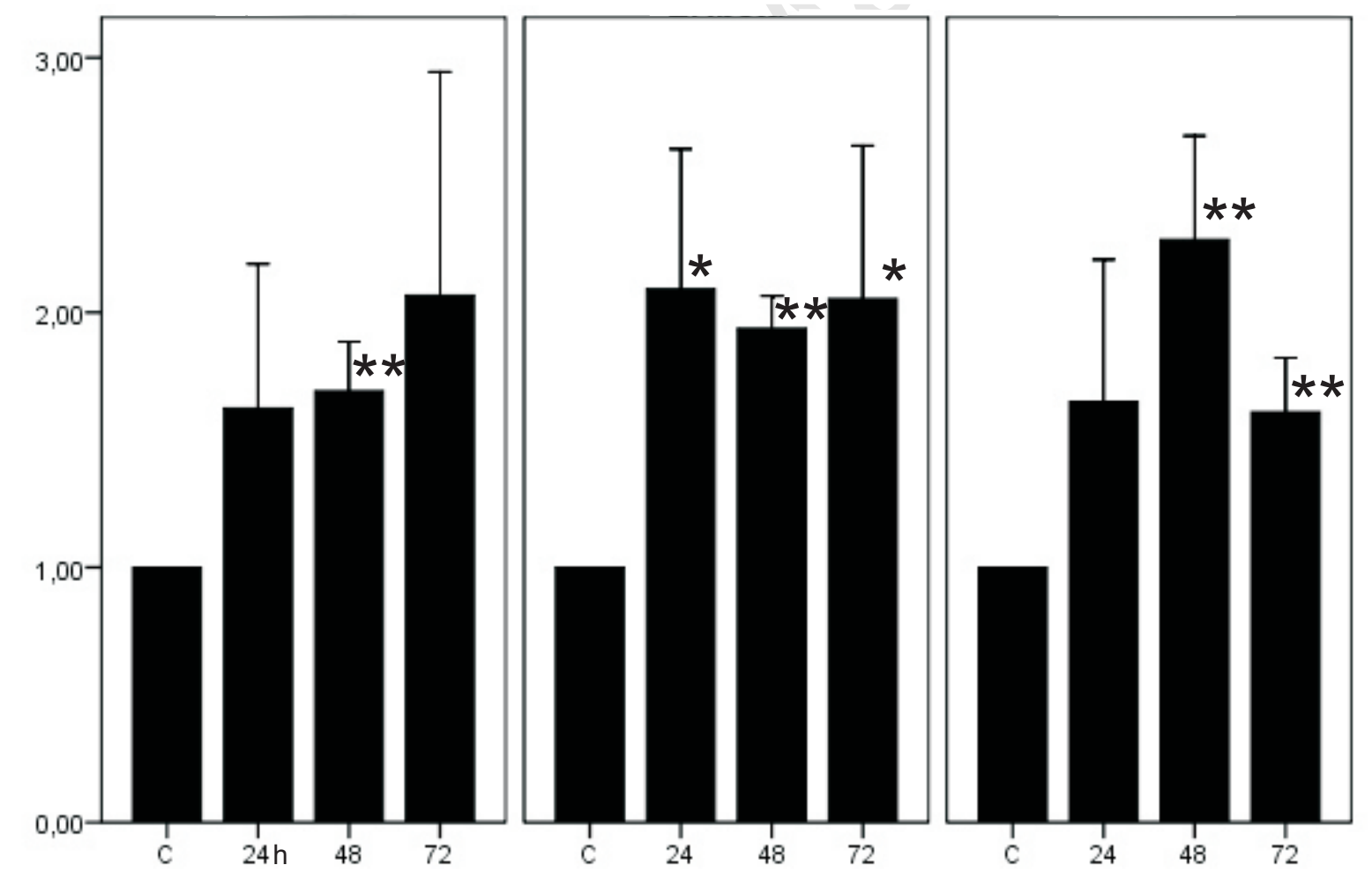

ER $\beta$
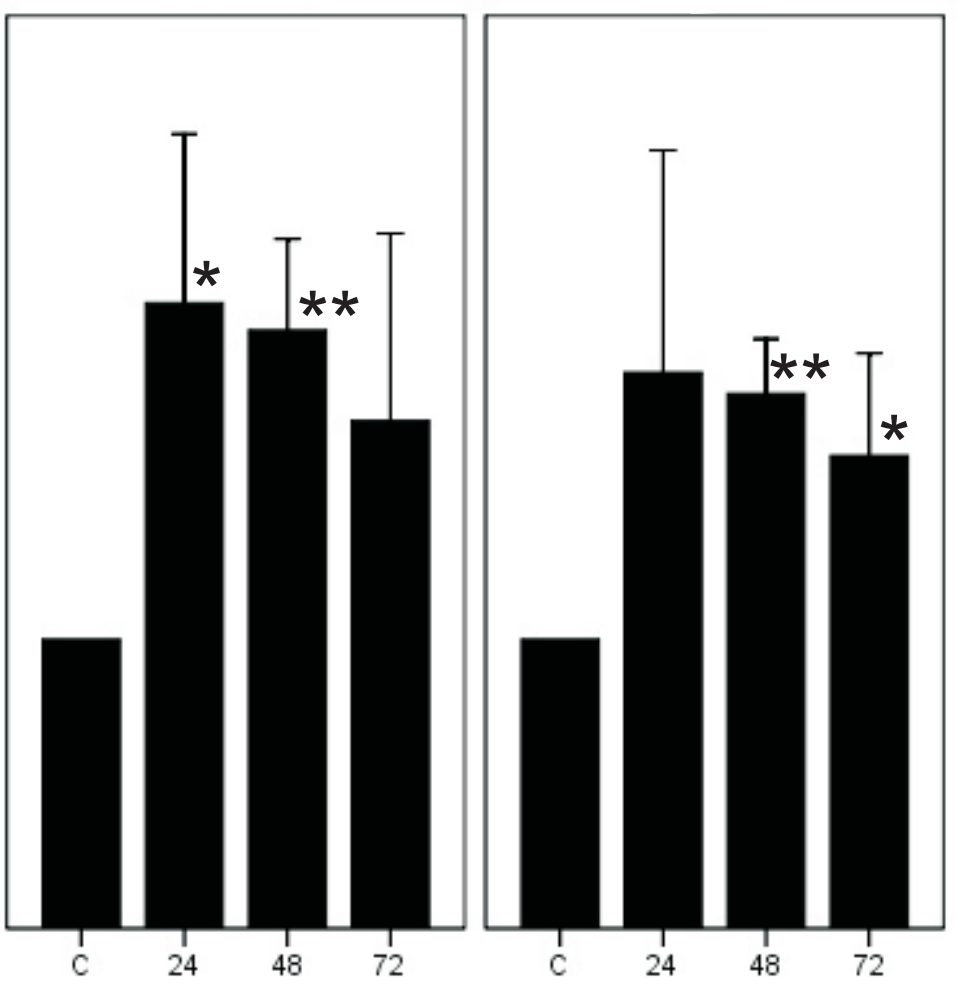

SNURF

C $\mathrm{ER} \alpha$

\section{$\mathrm{ER} \beta$}

SNURF

$\beta$-actin 
$\stackrel{\text { Figure }}{\text { FIG }} 3$

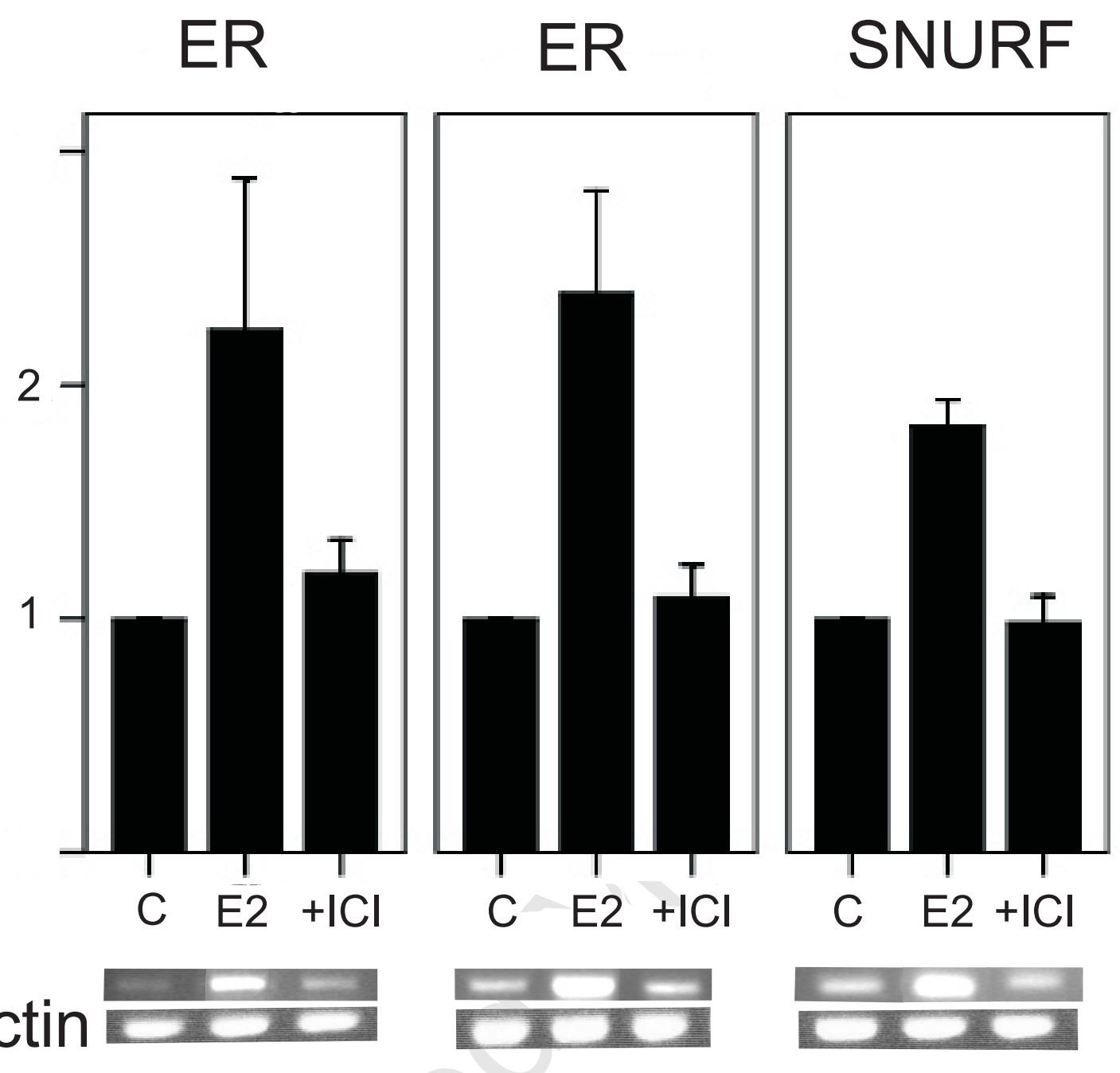

